\title{
UC-NRLF
}

B 3 071 bl 3 


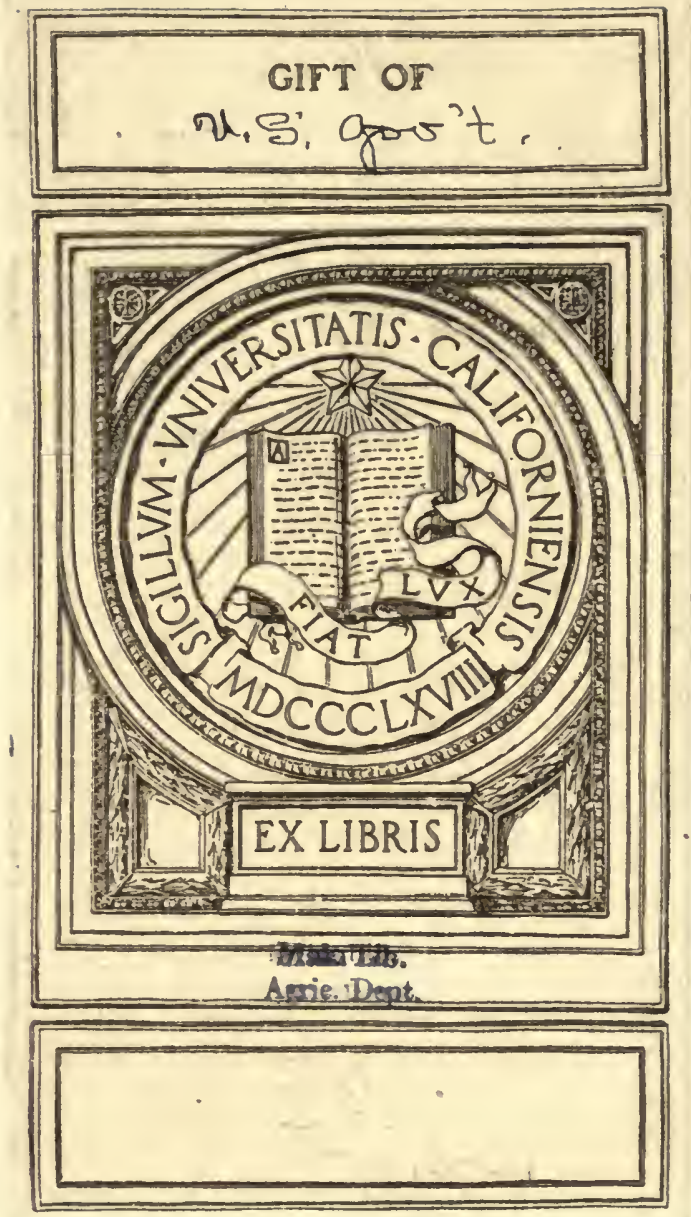




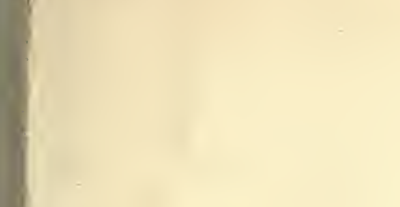

$$
\text { , }
$$




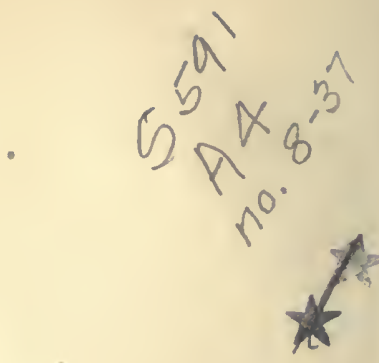

Main I ib.

Agric. Dept. 


\title{
United States Department of Agriculture,
}

\author{
BUREAU OF SOILS-CIRCULAR No. I9.
}

Milton Whitney, Chief of Bureau.

\section{SOILS IN THE VICINITY OF SAVANNAH, GA.: A PRELIMINARY REPORT.}

\author{
GENERAL DESCRIPTION OF THE REgION.
}

In order to determine the character of the soils in the vicinity of Savannah, Chatham County, Ga., and the adaptation of the different soils to the production of staple and special crops, a preliminary examination of the region immediately around Savannah was made in April, 1909.

Chatham County, Ga., lies along the south Atlantic coast, which forms the southeastern boundary of the county, and between the Savannah and Ogeechee rivers, which form its northeastern and southwestern boundaries. The county thus extends as a long peninsula or "river neck" between its boundary rivers and fronts for a distance of more than 20 miles on the Atlantic Ocean.

The principal city within its boundaries is Savannah, which in 1900 had a population of 54,244 inlabitants-a number considerably increased since the taking of the last federal census. The total population of Chatham County in 1900 was 71,239 . It is thus apparent that more than 75 per cent of the population of the county is gathered within the limits of the city. A considerable part of the remaining population is also to be found in the small towns along the various railroads. There is thus a very sparse rural population, compared with the dense urban population of the county. Savannah is one of the most important shipping centers on the south Atlantic coast, and in addition to regular ocean steamship lines to domestic and foreign ports it is served by four main trunk railway lines which give rapid transit to all the more northern seacoast and inland cities.

The highest altitudes in Chatham County do not reach more than 100 feet above tide level, and the altitudes given for the different railway stations indicate that the general range in height is from tide level to about 40 or 50 feet for the summits of the higher ridges, although the railroad altitudes are naturally at lower points than the

88559-Cir. $19-09-1$ 
crests of the more pronounced ridges. No accurate figures are available for the highest points in the county.

The general surface features in the vicinity of Savannah are those of a low plain, having an average altitude of 15 to 35 feet above tide level. This plain is surrounded by low, rounded ridges having a general northeast and southwest direction, interspersed with plains, hollows, and "bays" of all sizes and of intricate boundary. The river fronts in all cases rise from 5 to 15 feet above high tide, and particularly along the Savannah River are found level terraces or front lands which were the sites of extensive plantations during the earliest periods of colonial settlement and even to the time of the civil war.

Some of the river islands, and particularly the tidal marshes along the rivers and their principal tributaries, were diked and ditched at an early date for the reclamation of these soils for rice production. For the last forty years these improvements have been practically abandoned and have lost their efficiency coincident with the discontinuance of rice production as an extensive industry. Slight repairs and the restoration of flood gates and ditches would in many instances reestablish these fields in cultivable condition.

The fertility of these tide-marsh soils is beyond question, and with reestablished drainage they should ultimately constitute a valuable addition to the farm-land area of the county and State.

Only a small part of the rural section of Chatham County is occupied for agricultural purposes. In the immediate vicinity of Savannah and elsewhere along the principal railroad and highway routes some general and special farm crops are grown, but in the main the land is chiefly occupied by pine forest on the uplands and by hardwoods in the drainage ways and at lower levels.

With the exception of the river-front plantations and the abandoned rice fields there is little evidence of former agricultural occupation, and the majority of fields now tilled have been cleared of forest growth during the last forty years and occupied with market garden or general farm crops. As a result only small quantities of farm crops are produced for shipment, and in regard to many farm products the city of Savannah is dependent upon supplies shipped in from other sections of the State and the United States. This is especially true of dairy products and meats.

\section{CLIMATE.}

The following tables give the normal monthly and annual temperature, rainfall, and frost records for Savannah, and, for the sake of comparison, for Jacksonville, Fla., Charleston, S. C., and Wilmington, N. C. 
It will be seen from these records that the climatic conditions of Savannah are marked by moderate cold during the winter months and by moderate heat during the summer months. The proximity of Savannah to the seacoast gives rise to modifications of the extremes of heat and cold which are favorable not only to the production of winter and early spring crops, but also to the comfort of year-round residents of the section.

The dates of killing frosts indicate an average frost-free season of nine months, with light and infrequent frosts during the three winter months. Many truck crops can continue growth throughout the winter without protection, and cheesecloth cover would enable skillful growers to produce throughout the year all except the most delicate forms of vegetables. The long growing season is also favorable to the production of a succession of crops upon the same land during the year and allows the production of forage and staple crops during the summer upon land used during winter and spring for market garden or truck crops.

It is difficult to make direct comparisons between distant points in regard to many climatic features, owing to local variations from general records, but, so far as judgment is possible, the records given would indicate a season at Savannah about one week to ten days later than in northern Florida regions and from four days to one week earlier than at Charleston, S. C. This advantage in season is proportionately greater over still more northern truck-growing sections.

The rainfall is abundant for the production of practically all field crops and is well distributed throughout the growing season. Only in the case of celery would any irrigation prove necessary.

Normal monthly, scasonal, and annual temperature and precipitation: Savannah, Ga., compared with other southern points.

SAVANNAH, GA.

\begin{tabular}{|c|c|c|c|c|c|c|c|}
\hline \multirow[b]{2}{*}{ Month. } & \multicolumn{3}{|c|}{ Temperature. } & \multicolumn{4}{|c|}{ Precipitation. } \\
\hline & Mean. & $\begin{array}{c}\text { Absolute } \\
\text { maxi- } \\
\text { mum. }\end{array}$ & $\begin{array}{c}\text { Absolute } \\
\text { mini- } \\
\text { mum. }\end{array}$ & Mean. & $\begin{array}{l}\text { Total } \\
\text { amount } \\
\text { for the } \\
\text { driest } \\
\text { year. }\end{array}$ & $\begin{array}{l}\text { Total } \\
\text { amount } \\
\text { for the } \\
\text { wettest } \\
\text { year. }\end{array}$ & $\begin{array}{l}\text { Snow, } \\
\text { a verage } \\
\text { depth. }\end{array}$ \\
\hline & ${ }^{\circ} \mathrm{F}$. & $\circ F$ & ${ }^{\circ} \mathrm{F}$. & Inches. & Inches. & Inches. & Inches. \\
\hline December ......................... & 52 & 80 & 12 & 3.2 & 1.0 & 5.5 & $\ldots \ldots \ldots$ \\
\hline January...................... & 51 & 80 & 12 & 3.1 & 3.6 & 6.4 & ........... \\
\hline 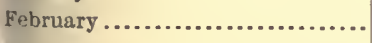 & 54 & 84 & 8 & 3.3 & 4.2 & 3.1 & (........... \\
\hline Winter.... & 52 & $\ldots \ldots \ldots$ & $\ldots \ldots \ldots$ & 9.6 & 8.8 & 15.0 & ........... \\
\hline March ....... & 59 & 88 & 24 & 3.7 & 2.3 & 3.1 & $\ldots .$. \\
\hline 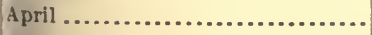 & $6 \dot{6}$ & 90 & 33 & 3.3 & 1.9 & 1.1 & .......... \\
\hline 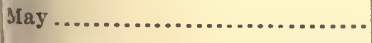 & 74 & 101 & 44 & 2.8 & 2.7 & 4.0 & (n........ \\
\hline Spring ..................... & 66 & $\ldots \ldots \ldots$ & ........... & 9.8 & 6.9 & 8.2 & ...... \\
\hline
\end{tabular}

[Clr. 19] 
Normal monthly, seasonal, and annual temperature and precipitation: Savannah, Ga., compared with other southern points-Continued.

SAVANNAH, GA.-Continued.

\begin{tabular}{|c|c|c|c|c|c|c|c|}
\hline \multirow[b]{2}{*}{ Month. } & \multicolumn{3}{|c|}{ Temperature. } & \multicolumn{4}{|c|}{ Precipitation. } \\
\hline & Mean. & $\begin{array}{l}\text { Absolute } \\
\text { maxi- } \\
\text { mum. }\end{array}$ & $\begin{array}{l}\text { Absolute } \\
\text { mini- } \\
\text { mum. }\end{array}$ & Mean. & $\begin{array}{l}\text { Total } \\
\text { amount } \\
\text { for the } \\
\text { driest } \\
\text { year. }\end{array}$ & $\begin{array}{l}\text { Total } \\
\text { amount } \\
\text { for the } \\
\text { wettest } \\
\text { year. }\end{array}$ & $\begin{array}{l}\text { Snow, } \\
\text { average } \\
\text { depth. }\end{array}$ \\
\hline June........... & $\begin{array}{l}{ }^{\circ} F . \\
79\end{array}$ & ${ }^{\circ} F$. & ${ }^{\circ} F$. & $\begin{array}{r}\text { Inches. } \\
6.1\end{array}$ & $\begin{array}{r}\text { Inches. } \\
6.8\end{array}$ & $\begin{array}{r}\text { Inches. } \\
8.1\end{array}$ & Inches. \\
\hline 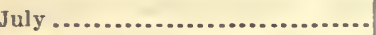 & 82 & 105 & 63 & 5. 8 & 3.7 & 7.9 & $\ldots$ \\
\hline August .......... & 81 & 102 & 61 & 7.9 & 6.4 & 14.4 & $\ldots$. \\
\hline Summer................... & 81 & ............. & - . & 19.8 & 16.9 & 30.4 & ..... \\
\hline September................... & 76 & 97 & 46 & 5.7 & 2.1 & 12.0 & \\
\hline October........................... & 67 & 92 & 37 & 3.7 & 1.0 & 7.7 & .... \\
\hline November............................. & 58 & 83 & 22 & 2.4 & 1.0 & 0.6 & .... \\
\hline Fall $\ldots . . . \ldots \ldots \ldots \ldots \ldots$ & 67 & ............. & (........... & 11.8 & 4.1 & 20.3 & ........ \\
\hline Annual........................... & 66 & 105 & 8 & 51.0 & 36.7 & 73.9 & $\ldots$ \\
\hline
\end{tabular}

Average date of last killing frost in spring, February 26; and of first in fall, November 27.

Date of latest In spring, April 5 ; and of earliest ln fall, November 1.

JACKSONYILLE, FLA.

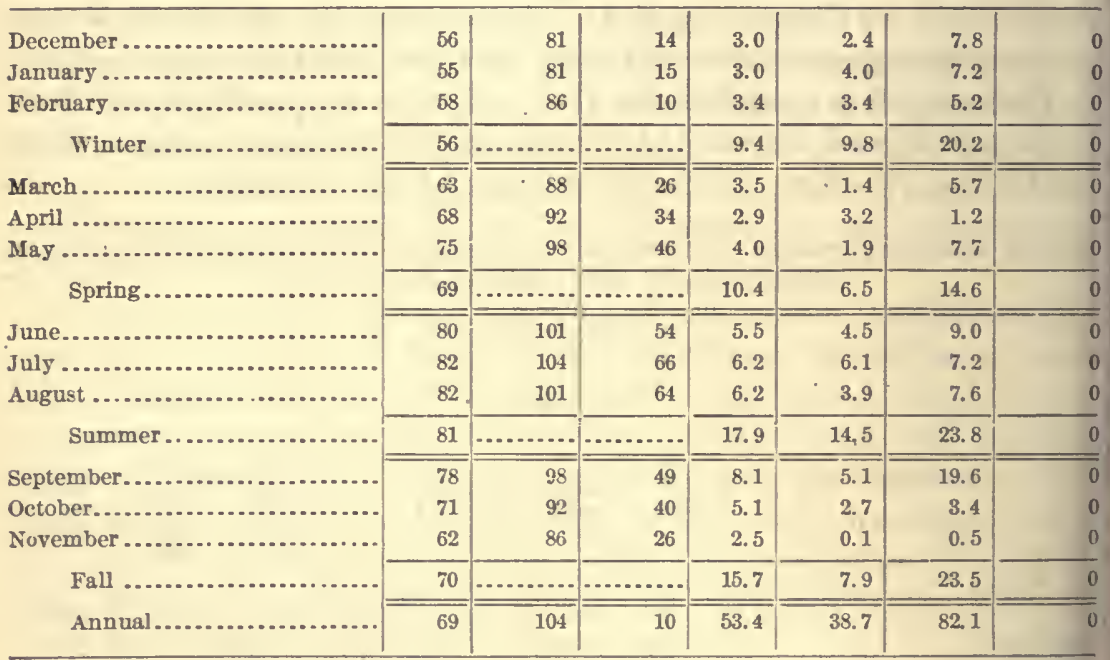

Average date of last killing frost in spring, February 19; and of first ln fall, December 6.

Date of latest in sprlng, April 6; and of earliest ln fall, November 12.

[C'r. 19] 
Normal monthly, seasonal, and annual temperature and precipitation: Savannah, Ga., comparcd with other southern points-Continued.

CHARLESTON, S. C.

\begin{tabular}{|c|c|c|c|c|c|c|c|}
\hline \multirow[b]{2}{*}{ Month. } & \multicolumn{3}{|c|}{ Temperature. } & \multicolumn{4}{|c|}{ Precipitation. } \\
\hline & Mean. & $\begin{array}{c}\text { Absolute } \\
\text { maxi- } \\
\text { mum. }\end{array}$ & $\begin{array}{l}\text { Absolute } \\
\text { mini- } \\
\text { mum. }\end{array}$ & Mean. & $\begin{array}{l}\text { Total } \\
\text { amount } \\
\text { for the } \\
\text { driest } \\
\text { year. }\end{array}$ & $\begin{array}{l}\text { Total } \\
\text { amount } \\
\text { for the } \\
\text { wettest } \\
\text { year. }\end{array}$ & $\begin{array}{l}\text { Snow, } \\
\text { average } \\
\text { depth. }\end{array}$ \\
\hline $\begin{array}{l}\text { December } . \ldots \ldots \ldots \ldots \ldots \ldots \ldots \ldots \ldots \\
\text { January } . \ldots \ldots \ldots \ldots \ldots \ldots \ldots \ldots \ldots \\
\text { February } \ldots \ldots \ldots \ldots \ldots \ldots \ldots \ldots \ldots \ldots\end{array}$ & $\begin{array}{r}\circ 1 \\
51 \\
50 \\
52\end{array}$ & $\begin{array}{l}{ }^{\circ} F . \\
78 \\
80 \\
80\end{array}$ & $\begin{array}{r}{ }^{\circ} F . \\
13 \\
10 \\
7\end{array}$ & $\begin{array}{r}\text { Inches. } \\
3.2 \\
3.6 \\
3.4\end{array}$ & $\begin{array}{r}\text { Inches. } \\
1.8 \\
2.2 \\
3.6\end{array}$ & $\begin{array}{r}\text { Inches. } \\
5.8 \\
.6 \\
2.4\end{array}$ & $\begin{array}{l}\text { Inches. } \\
\text { Trace. } \\
\text { Trace. } \\
\text { Trace. }\end{array}$ \\
\hline Winter .......... & 51 & ............. & ............. & 10.2 & 7.6 & 8.8 & Trace. \\
\hline March..... & 58 & 86 & 24 & 3.8 & 2.4 & 2.5 & Trace. \\
\hline April ......... & 65 & 89 & 32 & 3.2 & 1.6 & 4.9 & 0.0 \\
\hline May ............................... & 73 & 98 & 45 & 3.6 & 4.3 & 3.8 & .0 \\
\hline Spring. & 65 & ...... & ............ & 10.6 & 8.3 & 11.2 & Trace. \\
\hline June........ & 79 & 100 & 51 & 5.4 & 1.2 & 15.0 & .0 \\
\hline July .......................... & 82 & 104 & 64 & 7.4 & 5.5 & 11.3 & .0 \\
\hline August ........................... & 81 & 100 & 62 & 7.3 & 5.0 & 5.1 & .0 \\
\hline Summer. & 81 & $\cdots .$. & $\ldots \ldots \ldots$ & 20.1 & 11.7 & 31.4 & .0 \\
\hline September... & 76 & 95 & 49 & 5.5 & .4 & 11.3 & .0 \\
\hline October.............. & 67 & 93 & 39 & 4.0 & .9 & 14.3 & .0 \\
\hline November.................. & 58 & 83 & 23 & 3.0 & .8 & 1.4 & .0 \\
\hline Fail . & 67 & .... & ............ & 12.5 & 2.1 & 27.0 & .0 \\
\hline Annual. & 66 & 104 & 7 & 53.4 & 29.7 & 78.4 & Trace. \\
\hline
\end{tabular}

Average date of last killing frost in spring, March 3 ; and of first in fall, November 30. Date of latest in spring, April 2 ; and of earilest in fall, November 9.

WILMINGTON, N. C.

\begin{tabular}{|c|c|c|c|c|c|c|c|}
\hline December ........................ & 49 & 78 & 10 & 3.1 & 3.3 & 7.1 & 0.1 \\
\hline January ............................ & 47 & 80 & 9 & 3.6 & 1.4 & 2.4 & .1 \\
\hline February...$\ldots \ldots \ldots \ldots \ldots \ldots \ldots$ & 49 & 80 & 5 & 3.4 & 3.3 & 1.6 & 1.0 \\
\hline Winter .... & 48 & $\cdots .$. & $\cdots$ & 10.1 & 8.0 & 11.1 & 1.2 \\
\hline March ........... & 55 & 87 & 20 & 3.6 & 3.6 & 4.5 & .1 \\
\hline 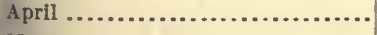 & 61 & 90 & 28 & 2.8 & 1.6 & 6.6 & .0 \\
\hline 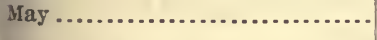 & 70 & 97 & 38 & 4.0 & 2.3 & 2.4 & .0 \\
\hline Spring.... & 62 & ..... & ..... & 10.4 & 7.5 & .13 .5 & .1 \\
\hline June........... & 77 & 100 & 51 & 5.6 & 3.2 & 7.5 & .0 \\
\hline July ................ & 80 & 103 & 58 & 6.7 & 3.0 & 9.4 & .0 \\
\hline 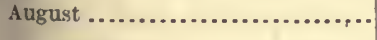 & 79 & 99 & 56 & 7.0 & 2.4 & 10.5 & .0 \\
\hline Summer ..................... & 79 & $\ldots \ldots \ldots$ & $\ldots \ldots \ldots \ldots$ & 19.3 & 8.6 & 27.4 & .0 \\
\hline September........................ & 74 & 96 & 42 & 5.4 & 3.6 & 20.1 & .0 \\
\hline 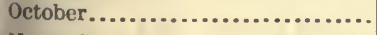 & 64 & 92 & 32 & 3.9 & 3.2 & 6.7 & .0 \\
\hline November................. & 55 & 83 & 20 & 2.1 & 3.8 & 4.9 & Trace. \\
\hline Fall $. . . . \ldots \ldots \ldots \ldots . . . . . . .$. & 64 & $\ldots \ldots \ldots$ & .......... & 11.7 & 10.6 & 31.7 & Trace. \\
\hline Annual....................... & 63 & 103 & 5 & 51.5 & 34.7 & 83.7 & 1.3 \\
\hline
\end{tabular}

Average date of last kiliing frost in spring, March 27 ; and of first in fall, November 15. Date of iatest in spring, May 1; and of earliest in fall, October 16.

[Cir. 19] 
GENERAL FEATURES OF THE SOILS.

The entire area of Chatham County, Ga., falls within the seaward section of the Atlantic and Gulf Coastal Plain. This extensive soil province stretches from Long Island, N. Y., southward to the Florida peninsula, and thence swings westward along the Gulf of Mexico to the Rio Grande. It is a region of low relief and one much intersected by sounds, estuaries, and the lower courses of numerous rivers which have their headwaters in the Mountain and Piedmont regions farther inland. Through the Coastal Plain section of the country a majority of the navigable rivers flow from the inland regions to the sea. It is, therefore, largely accessible by water to vessels of medium and light draft. Chatham County is bordered by two such rivers, the Savannah and Ogeechee.

The materials comprising Chatham County, in common with other Coastal Plain counties, are principally unconsolidated sands and clays, with occasional minor deposits of gravel. This material has been eroded from the surface of inland regions and transported seaward by ancient streams, to be deposited as thick stratified beds of marine and river sediments. The upland portion of Chatham County is built up of mottled clays and sandy clays, probably of Lafayette age, quite generally covered to a depth ranging from a few inches to many feet by the yellow to gray sands and sandy loams of the Columbia formation. The light-gray to yellow fine sand, the fine sandy loam, and the sandy clay of all of the higher elevations consist of such materials, while the mottled sandy clay which outcrops along the lower slopes of the ridges and is found in the deeper railway cuts was probably formed as a marine sediment in Lafayette time.

On the level uplands and in the minor depressions between ridges the marine deposits of the Columbia formation have been locally modified because of insufficient drainage and the accumulation of considerable amounts of partly decayed organic matter. This has given rise to a mucky black, dark-brown, or dark-gray surface soil, varying from a few inches to 3 or 4 feet in depth.

The county also contains along the rivers considerable areas of tide-marsh lands of alluvial origin. A part of this land was formerly reclaimed and planted to rice, but this occupation has practically ceased in recent years. The surface of the tide marshes is covered by turf or peat, or else by partly decayed organic matter and silt. The subsoil is most frequently a drab or gray silt clay. It is saturated at high tide and practically occupied only by swamp vegetation, but would be easily reclaimable for agricultural use.

The immediate coast of the county is occupied by sandy beaches and dunelike ridges of gray or white sand. Hollows and trough- 
like depressions are found among these ridges where smatl areasiof mucky surface material have accumulated.

These different materials, under the varied conditions of their derivation, deposition, and recent condition, have given rise to soils of the Norfolk and Portsmouth series, in addition to the tide marshes and coast sands. In the brief preliminary examination of the soils in the vicinity of Savannah it was possible to identify with precision two of the more important members each of the Norfolk and Portsmouth series. That other members of both series are associated with these was also observed, but only the more extensive and at the same time more directly valuable trucking soils were examined in any detail. It was impossible in the time available to map or to estimate the total area in acres or square miles of the four important types, but thousands of acres of each exist within easy driving distance of the shipping points in Savannah.

\section{NORFOLK SERIES.}

The types of the Norfolk series are marked by light-gray to yellow sandy surface soils, underlain by yellow sandy or sandy clay subsoils. The soils of this entire series, from its more northern extension southward to the Gulf coast section, are special purpose rather than general farming soils. The series comprises the most important truck soils of the Coastal Plain. Each of the soils of this series is adapted to a great variety of truck crops. Moreover, the fact that the several soils of the series, differing in texture, all occur in nearly every part of the coast section gives opportunity in each locality for growing both early and late truck crops. At the same time the support of the work stock, the preservation of the soil from erosion, and the maintenance of the organic matter of the soil by occasional green manuring can be provided for by growing the necessary forage and cover crops, to which most of the members of the series are adapted in greater or less degree.

Of this [Norfolk] series the fine sand, taken all in all, is the leading soil for general trucking. In earliness it lies between the coarser soils on the one hand and the finer on the other. It is less leachy and droughty than the Norfolk sand or coarse sand, and is more easily kept in a productive state. Besides the lighter truck crops, it is a valuable soil in Florida for the production of a fine grade of Sumatra wrapper tobacco, and in North Carolina and Virginia for cigarette tobacco and peanuts. In Maryland it is the best soil tor the French type of tobacco. In trucking areas large acreages are devoted to strawberry culture. In the sea islands of South Carolina it is the principal soil upon which the long-staple cotton industry has been developed.

The fine sandy loam is not so valuable for early truck as the fine sand, but is an excellent medium to late truck soil, and in some sections it is known as "cabbage land." In North Carolina it is esteemed a better cigarette-tobacco soil than the sandy loam and fully equal to the fine sand. It is better for

[Cir. 19] 
general farming than the lighter soils of the series, and is used extensively in the production of cotton, being the best of the Norfolk series of soils for growing this crop. In certain parts of Maryland it is a fine general-purpose soil, giving good yields of wheat, corn, and hay in addition to heary truck and fruit, principally peaches. ${ }^{a}$

\section{NOBFOLK FINE SAND.}

The Norfolk fine sand in the vicinity of Savannah, Ga., is practically identical with the extensive areas of this type which have been investigated along the Atlantic coast from the Potomac River south. The surface soil to a depth of 8 or 10 inches is a fine-grained, mellow sand containing varying quantities of partly decayed organic matter. Where it has been enriched by large applications of stable manure or still contains the leaf mold derived from original vegetation it is light-brown in color. In the majority of fields where clean cultivation has been practiced for some time, with little or no restoration of organic matter, it is a light yellow or gray. The subsoil from 10 inches to a depth of 36 inches or more is a finegrained, mealy, light-yellow sand, frequently somewhat loamy and occasionally mottled with gray or orange below 24 inches in depth.

The Norfolk fine sand occupies the crests of all of the higher ridges west and north of Savannah, stretches along the narrow river terraces at an elevation of from 6 to 15 feet above tide level, and is also found upon the better drained and more elevated portions of the gently rolling plains to the east and south of the city.

Because of its considerable thickness over the underlying sandy clay, its elevated position, and its moderate porosity, it is a naturally well-drained, warm, and early soil, especially well suited to the forcing of winter and early spring crops to quick maturity. In the vicinity of Savannah few if any slopes or grades occur within this soil type, such as to render machine cultivation difficult or to impose the necessity of contour cultivation to prevent erosion. As a result, the greater portion of the Norfolk fine sand is either cultivated or available for clearing and cultivation whenever the possibilities of profitable market gardening and trucking may warrant an extension of the tilled area. The native timber growth is chiefly pine, and the cost of clearing timbered fields would be nearly or quite met by the value of the lumber and wood secured. The stumps left after clearing decay rapidly and offer little obstacle to cultivation after the second or third year of agricultural occupation. There is some undergrowth, but in general not sufficient to interfere seriously with the utilization of this type for farm purposes.

a Solls of the United States. Milton Whitney. Bulletin 55, Bureau of Soils, U. S. Dept. of Agriculture. Pp. 104-105.

[Cír. 19] 
In the immediate vicinity of Savannah there are several truck farms which include areas of the Norfolk fine sand. Its easy cultivation and the rapidity with which crops planted upon it mature are locally known and appreciated. To this local evidence of its especial availability for truck growing may be added the statement that the Norfolk fine sand is the earliest winter and spring truck soil along the middle and south Atlantic coasts which at the same time is sufficiently retentive of moisture to assure the maturity of medium to large yields per acre. There are other more porous, warmer soils, notably the Norfolk sand or Norfolk coarse sand, which are used for the production of truck crops, but with the exception of the most northern trucking regions they balance early maturity by diminished yields.

A considerable portion of the trucking industry at present established near Savannah is conducted upon the Norfolk fine sand. The largest acreage given to any one crop is undoubtedly planted to early Irish potatoes. The seed used is chiefly northern grown and the potatoes are planted about February 1. The tubers have usually reached marketable size by May 15, and the crop is harvested from that date to June 10. This clears the ground in sufficient time for the production of another crop of potatoes for seed, or, better, for the production of a summer crop of cowpeas to be cut for hay. The yield of early potatoes will usually average from 40 to 50 barrels, of $2 \frac{1}{2}$ bushels each, per acre, and, while the prices secured depend largely upon the time of maturity of the crop, $\$ 3$ a barrel can usually be depended upon as an average price for the crop as it runs.

In the production of Irish potatoes large quantities of carefully composted stable manure are used, and this is secured from city stables. In addition the best growers apply about 1,000 pounds per acre of high grade chemical fertilizer, selling at about $\$ 40$ per ton, and analyzing 4 to 5 per cent of potash and 6 to 7 per cent ammonia. The potash is usually in the sulphate form for use on the potato crop, and nitrate of soda frequently supplies the ammonia, though the sulphate of ammonia is considered better by some successful growers.

Considerable attention is also paid to the production of snap beans on the Norfolk fine sand and upon other soil types near Savannah. The beans are planted during the last week in February and the first picking is made during the first week in May. The beans are marketed in 3-peck baskets, which bring from $\$ 2.50$ to $\$ 3$ a basket for the first shipments. Shipment is discontinued when the price sinks below $\$ 1$ a basket, since the cost of basket, picking, and freight amounts to two-thirds that sum.

A little lettuce is raised on the Norfolk fine sand, though practically none is shipped.

SS559-Cir. $19-09-2$ 
Cucumbers are also raised on the type. The seed is planted during the month of March, and by June 1 the earliest cucumbers have been picked. They are also marketed in 3-peck baskets, which sell during the early part of the season at $\$ 2.50$ and later sink to 75 cents, at which price shipment usually ceases. The yield per acre is decidedly variable, ranging from 200 baskets to many times that number.

It will thus be seen that on the best early truck soil, the Norfolk fine sand, sereral intensirely farmed truck crops are already produced, though they are planted only by a few progressive truck growers and the total acreage is limited. In the case of all of these crops good profits are secured, and the local adaptability of the soil type to the cultivation of early Irish potatoes, snap beans, cucumbers, and lettuce is fully demonstrated. When consideration is also given to the uniform successes which have been achieved with these and several additional truck crops upon the Norfolk fine sand in the other established trucking areas, there can be no doubt as to the successful derelopment of the Norfolk fine sand as a truck soil in the vicinity of Savannah. Thousands of acres of the type-some cultivated, some wild land-exist to the enst, north, and west of the city within easy access to shipping facilities, both rail and water.

The following table shows the texture of the Norfolk fine sand:

Mechanical analyses of Norfolk fine sand.

\begin{tabular}{|c|c|c|c|c|c|c|c|c|}
\hline Number. & Description. & $\begin{array}{c}\text { Fine } \\
\text { gravel. }\end{array}$ & $\begin{array}{c}\text { Coarse } \\
\text { sand. }\end{array}$ & $\begin{array}{l}\text { Medium } \\
\text { sand. }\end{array}$ & $\begin{array}{l}\text { Fine } \\
\text { sand. }\end{array}$ & $\begin{array}{l}\text { Very fine } \\
\text { sand. }\end{array}$ & Silt. & Clay. \\
\hline 20397 . & Soil......... & $\begin{array}{r}\text { Per cent. } \\
0.6\end{array}$ & $\begin{array}{r}\text { Per cent. } \\
6.9\end{array}$ & $\begin{array}{r}\text { Per cent. } \\
5.9\end{array}$ & $\begin{array}{r}\text { Per cent. } \\
43.8\end{array}$ & $\begin{array}{r}\text { Per cent. } \\
24.9\end{array}$ & $\begin{array}{r}\text { Per cent. } \\
13.5\end{array}$ & $\begin{array}{r}\text { Per cent. } \\
4.6\end{array}$ \\
\hline 20398 ............ & Subsoil ..... & .5 & 5.8 & 5.0 & 52.7 & 17.3 & 13.2 & 5.7 \\
\hline
\end{tabular}

NORFOLK FINE SATDY LOAM.

The surface soil of the Norfolk fine sandy loam to a depth of 10 inches or more is a fine, loamy yellow sand. The subsoil in the vicinity of Savannah is unusually deep and consists of a brown to yellow or gray loamy sand, which becomes more loamy and coherent with increasing depth, and at 24 to 34 inches grades into a mottled, red and yellow, sticky sandy clay. The type lies generally at lower levels than the ridges occupied by the Norfolk fine sand, and for this reason there is a less depth of fine sand overlying the sandy clay. The position of the sandy clay nearer the surface renders both the soil and subsoil of the Norfolk fine sandy loam more retentive of moisture than the fine sand, and therefore its crops are not matured in quite so short a season as on the fine sand. The yields per acre are not infrequently greater when conditions of cultivation are 
equally good, and this compensation leads to a considerable occupation of the type for early truck crops. For certain later truck crops the Norfolk fine sandy loam is to be preferred over the Norfolk fine sand. It is also better adapted to cotton, corn, and bright tobacco, when it is desired to produce these crops in connection with market gardening or trucking.

In the present trucking region around Savannah the crops already described on the Norfolk fine sand are also produced on the fine sandy loam with nearly as good results. The area of Norfolk fine sandy loam in the immediate vicinity of the city was apparently less than of the fine sand, and occurred around the slopes which mark the margins of the more sandy ridges. Level areas of the Norfolk fine sandy loam occur east and south of Savannah, and nowhere in the type are the slopes too steep for profitable cultivation.

The Norfolk fine sandy loam is especially suited to the production of winter and early spring cabbage, though this crop is not grown about Savannah. Its adaptation to the crop is so well known and so highly appreciated in other southern trucking areas that the type is in such localities known as "cabbage land." From 150 to 230 crates of cabbage, of 100 pounds each, can be grown on an acre of Norfolk fine sandy loam, and the crates sell at $\$ 5$ for extra early to $\$ 1.50$ for the later crop. When a crop of cabbage has been sold, either a suminer forage crop, a late potato crop, or a crop of green peas or sugar corn for canning purposes can be grown the same season. If such a rotation is followed the land is benefited, the fertilizer bill is reduced through the production of green manure or stable manure from by-products, and the cost of the production of the first or truck crop is not infrequently paid by the profits from the second crop-the forage, seed, or canning crop.

\section{PORTSMOUTH EERIES.}

The Portsmouth series is characterized by dark-gray to black surface soils, underlain by yellow, gray, or mottled yellow and gray subsoils. The dark, mucky appearance of the soils is due to an accumulation of partly decayed organic matter during an earlier or existing swampy condition. The series as a rule is rather poorly drained naturally, and to bring it under cultivation open ditches and subsoil tile drains are usually necessary. The soils of the Portsmouth series may be considered as intermediate between the light-colored, welldrained Norfolk soils on the one hand and the deep accumulations of organic material of Peat and Swamp areas on the other.

Notwithstanding their naturally poorly drained condition, the soils of this series are in most instances easily reclaimed by ditching, and when brought into proper condition are highly productive for both

[Cir. 19] 
the general farm and special crops. The sandy members of the series are very desirable for strawberries, especially for late varieties. They are also well suited to truck crops, such as cabbage, kale, lettuce, and root crops, and could be used to advantage for celery, onions, and other crops that thrive in soils of high organic matter content. In Duplin County, N. C., the sand and fine sandy loam have been found particularly adapted to the growing of bulbs, large yields of tuberoses, dahlias, and cannas being secured. The heavier members are used chiefly for corn, small grain, and grass, though they are also used in places for celery, onions, and cabbages.

PORTSMOUTH FINE SAND.

The Portsmouth fine sand to a depth of more than 1 foot, usually to a depth of 16 or 18 inches in the vicinity of Savannah, consists of a dark-gray to dark-brown fine loamy sand, which is evidently a combination of fine sand with the mucky remains of organic matter. The subsoil to a depth of 3 feet or more is a rusty brown fine sand, sometimes almost black or mottled dark brown and gray. In all of the borings taken the subsoil was found to be saturated with water (April 20-21, 1909), even in cultivated fields which had been artificially drained by open ditches. In undrained fields the water table (zone of saturation) stood a few inches below the surface.

The Portsmouth fine sand occupies the nearly level but somewhat depressed areas between the higher ridges and in the central portions of the flatter upland sections. It is also found in the "bays," draws, and partially established drainage channels. This type grades into the Norfolk fine sandy loam or the Norfolk fine sand along the higher margins and into other members of the Portsmouth series toward the central and lower portions of the poorly drained areas. All of the soils of the Portsmouth series owe their dark color and mucky characteristics to imperfect natural drainage, either present. or recently corrected. The continued luxuriant growth of deciduous trees, vines, and other undergrowth has supplied a large amount of organic matter, which has annually fallen upon moist or watersoaked soil. Instead of complete destructive decomposition a partial decay and partial preservation of the carbonized organic matter has ensued, and the mingling of this vegetable matter with the fine sand and silt washed or blown in from dryer uplands has resulted in the formation of the soils of the Portsmouth series.

Before any portion of the Portsmouth fine sand can be successfully tilled it must be cleared of rank vegetation and so thoroughly drained by open main ditches and tiled laterals that the level of standing water in the subsoil is lowered to a depth of not less than 18 inches from the surface of the land. When thus effectively drained the 
Portsmouth fine sand has in numerous instances proven to be a fertile soil, capable of producing very valuable special market garden and truck crops.

The Portsmouth fine sand will produce large yields of Irish potatoes, but these will not usually mature at so early a date as upon the types of the Norfolk series already described. Moreover, the quality of the potatoes is usually inferior, owing to a tendency to turn brown when cooked and, in the larger tubers, to form hollow centers where decay is likely to start.

The Portsmouth fine sand is well suited to the production of large yields of the later truck crops. Large yields of early spring cabbages can be secured. Late strawberries produce exceptionally large yields of fruit of fair quality. Radishes and onions for the bunch trade are certain of heavy yields.

It is as a lettuce soil that the Portsmouth fine sand can frequently be most profitably used. In the northern markets the head varieties are most in demand. The lettuce is grown as a winter or very early spring crop, and where a specialty is made of lettuce special methods are employed to secure immunity from severe frosts. Large frames, from 18 to 20 feet wide, 2 feet high at the sides and 4 feet high at the center, are erected in the field to any convenient length. Over each frame a light removable cheesecloth cover is spread. This covers the bed completely but does not touch the plants. Whenever unusual cold or frost is anticipated the cheesecloth covering is placed over the beds and a warm-air chamber formed sufficient to preserve the tender plants against any normal winter frosts. After the danger from frost is past and the warm sunlight is desired directly upon the growing plants, the cheesecloth is rolled back and the bed is restored to field conditions.

Lettuce plants are usually started in small frames, covered with either cheesecloth or glass, and transplanted to the field frames between November 1. and January 1. The plants are set in rows from 14 to 18 inches apart and cultivated entirely with hoe and rake. The earliest heads are usually ready for cutting during the period from twelve to fourteen weeks after the date of transplanting. In some localities two crops of lettuce are grown in the beds each season. In such cases the early crop is set late in August or early in September and cut from November 1 to December 1. The later crop is set late in December and is marketed in February or March. The spring crop usually is more certain and gives larger yields. Where irrigation is possible the fall and winter crop can be raised to advantage, since drought is the chief obstacle to its production.

The preparation of the soil is one of the fundamental operations in lettuce production. Even on naturally fertile soils like the Ports- 
mouth fine sand or Portsmouth fine sandy loam it is held to be necessary to use as high as 100 loads of well-rotted stable manure per acre in the beds. In addition 500 to 2,000 pounds per acre of highgrade commercial fertilizer is used by the most successful growers.

The North Carolina Experiment Station ${ }^{a}$ has recommended the following formula for the use of lettuce growers in that State: Acid phosphate, 900 pounds; dried blood, 600 pounds; muriate of potash, 400 pounds. This mixture is for application at the rate of 500 to 1,000 pounds per acre, in addition to composted stable manure. In practice it has been found advisable to apply the mixture several days in advance of the transplanting of the lettuce, in order to avoid any possible caustic action of the potash salt upon the tender roots of the young plants. For special forcing of the growing crops, nitrate of soda is raked in as a surface dressing as the growth of the crop may seem to require. It is believed by many growers that cotton-seed meal can not profitably be used as a source of nitrogen for lettuce crops, as it is claimed the meal is conducive to rotting of the plants.

More than two or three successive crops of lettuce can not be produced in the same beds. The most successful growers usually produce one excellent crop and then devote the beds to the production of other truck crops, like snap beans, collards, or early Irish potatoes, sweet potatoes, or even a crop of cowpeas. Beets and cucumbers in the lettuce beds would also do well when the beds are made up from the Portsmouth fine sand.

In some of the Atlantic coast trucking regions crops of Big Boston lettuce have been cut which yielded a gross return of $\$ 1,800$ per acre and a handsome profit even after deducting large bills for manure, fertilizer, hand labor, and the cost of installing and maintaining the frames.

Among the other market garden and truck crops suited to the Portsmouth fine sand; beets, carrots, collards, and eggplant may be enumerated.

The following table gives the results of mechanical analyses of samples of the soil and subsoil of the Portsmouth fine sand:

Mechanical analyses of Portsmouth fine sand.

\begin{tabular}{|c|c|c|c|c|c|c|c|c|}
\hline Number. & Description. & $\begin{array}{c}\text { Fine } \\
\text { gravel. }\end{array}$ & $\begin{array}{l}\text { Coarse } \\
\text { sand. }\end{array}$ & $\begin{array}{l}\text { Medium } \\
\text { sand. }\end{array}$ & $\begin{array}{l}\text { Fine } \\
\text { sand. }\end{array}$ & $\begin{array}{l}\text { Very fine } \\
\text { sand. }\end{array}$ & Silt. & Clay. \\
\hline $20399 \ldots$ & Soil.......... & $\begin{array}{r}\text { Per cent. } \\
0.2\end{array}$ & $\begin{array}{r}\text { Per cent. } \\
7.3\end{array}$ & $\begin{array}{r}\text { Per cent. } \\
8.7\end{array}$ & $\begin{array}{r}\text { Per cent. } \\
72.5\end{array}$ & $\begin{array}{r}\text { Per cent. } \\
2.2\end{array}$ & $\begin{array}{r}\text { Per cent. } \\
5.5\end{array}$ & $\begin{array}{r}\text { Per cent. } \\
3.7\end{array}$ \\
\hline $20400 \ldots \ldots \ldots \ldots$ & Subsoil ...... & .2 & 6.4 & 8.2 & 71.3 & 2.1 & 5.6 & 5.8 \\
\hline
\end{tabular}

${ }^{a}$ Bul. No. 132, North Carolina Exp. Sta. 
The surface soil of the Portsmouth fine sandy loam, to a depth of 10 inches or more, is a black mucky loam. It is soft, friable, and absorbent of moisture and at the same time sufficiently coherent to be adhesive and loamlike when tilled in a moist condition. The subsoil to a depth of 30 inches or more is a dark-brown or rustybrown fine sandy loam, not infrequently mottled with gray or drab. It may contain small gravellike iron concretions. The subsoil under natural conditions is usually saturated with water, and unless drainage channels have been opened the surface soil is not infrequently wet and swampy during a large portion of the year.

In position the Portsmouth fine sandy loam occupies the lowest depressions and frequently the centers of the "bays" or swamps. In the immediate vicinity of Savannah many of these swampy areas have been artificially drained as a sanitary measure, and considerable areas of both the Portsmouth fine sandy loam and Portsmouth fine sand are already practically reclaimed. Small acreages are occupied by various market garden crops, oats, vetches, and some cowpeas.

The Portsmouth fine sandy loam owes its dark mucky appearance and high percentage of organic matter to the causes already given under the Portsmouth fine sand. It is a deeper accumulation of vegetable mold, less mixed with coarse particles of mineral matter, but still containing considerable amounts of fine sand, silt, and clay. Until drained it is practically useless for agricultural purposes, but when adequately drained it is one of the most valuable special truck soils along the south Atlantic coast.

For celery production no soil in the vicinity of Savannah can equal the Portsmouth fine sandy loam, though profitable crops can certainly be grown upon the Portsmouth fine sand.

The results of mechanical analyses of the soil and subsoil of the Portsmouth fine sandy loam are given in the following table:

Mechanical analyses of Portsmouth fine sandy loam.

\begin{tabular}{|c|c|c|c|c|c|c|c|c|}
\hline Number. & Description. & $\begin{array}{c}\text { Fine } \\
\text { gravel. }\end{array}$ & $\begin{array}{c}\text { Coarse } \\
\text { sand. }\end{array}$ & $\begin{array}{l}\text { Medium } \\
\text { sand. }\end{array}$ & $\begin{array}{l}\text { Fine } \\
\text { sand. }\end{array}$ & $\begin{array}{l}\text { Very fine } \\
\text { sand. }\end{array}$ & Silt. & Clay. \\
\hline $20401 \ldots$ & Soil......... & $\begin{array}{r}\text { Per cent. } \\
0.0\end{array}$ & $\begin{array}{r}\text { Per cent. } \\
1.4\end{array}$ & $\begin{array}{r}\text { Per cent. } \\
0.6\end{array}$ & $\begin{array}{r}\text { Per cent. } \\
55.5\end{array}$ & $\begin{array}{r}\text { Per cent. } \\
7.9\end{array}$ & $\begin{array}{r}\text { Per cent. } \\
19.6\end{array}$ & $\begin{array}{r}\text { Per cent. } \\
14.0\end{array}$ \\
\hline $20402 \ldots \ldots \ldots \ldots$ & Subsoil ..... & .0 & .5 & .4 & 62.0 & 8.6 & 14.4 & 13.6 \\
\hline
\end{tabular}

The celery plant will grow under a considerable range of soil con-. ditions, but the most extensively developed celery production in all parts of the United States has uniformly been upon peat or muck soils in the North, East, and Southwest, and upon mucky loams, or sandy loams, in the Southern and Southeastern States. For profitable production upon a commercial scale celery requires a cool, moist,

[Cir. 19] 
friable soil, and in order that clean cultivation and the proper banking of the rows for purposes of blanching may be accomplished the loamy and mucky soils are found far superior to heavy loams or sands for celery culture. While moist soil is essential for celery production, the saturation of the soil near the surface is undesirable both from the standpoint of easy tillage, of early maturity, and of liability to fungus diseases. While no absolute rule can be laid down, it is safe to say that the zone of soil saturation (water table) must be reduced to a depth of 18 inches below the surface of the field in order to assure success with celery. Although moisture in considerable quantities is necessary, it is circulating soil moisture and not stagnant ground water which is required for plant growth. Circulating moisture, whether derived from natural rainfall or artificial irrigation, is beneficial because of its warmth, the included air which it carries, and its effect in conducting the dissolved soil material from place to place around the growing roots. Stagnant water is cold, usually devoid of included air, and not infrequently charged with noxious dissolved material of both mineral and organic origin. It also shuts out the circulation of soil atmosphere, while circulating soil moisture rarely does this, but rather facilitates the aeration of the soil.

Because muck and peat soils and mucky soils like the Portsmouth fine sand and Portsmouth fine sandy loam are capable of retaining considerable amounts of moisture, are usually cool, and are always easily tilled and banked up along the rows, they have wisely been chosen by the best celery growers in the south Atlantic States for the profitable production of this crop on an extensive scale.

Celery is produced in small quantities in a large number of States, under practically all of the varied climatic conditions of the continental portion of the United States. The natural habitat of wild celery, however, is in swampy, peaty localities, and cultivated celery is not largely changed from this habit of growth.

For celery cultivation it is necessary to start the plants from the seed sown in forcing beds. Some of the best growers transplant twice, each time cutting off the taproot of the plant to force large growth of the lateral roots near the surface of the soil. A single transplanting from the seed bed directly to the field is far more common. From 20,000 to 30,000 plants are set per acre, and two-thirds to three-fourths of the plants should mature salable celery.

Usually the rows are run 4 feet apart, and the plants are spaced 6 to 9 inches apart in the row. The rows are furrowed out by a special plow, and the plants are set in the bottoms of the trenches. The plants must always be watered as set. During the period of growth the ridges between rows are gradually cultivated into the

[Cir. 19] 
row, and the banking up is finished when the stalks have reached a length of 12 to 18 inches, depending upon the variety raised. Other blanching methods are employed, usually at much greater expense, which is frequently justified by the improvement in the quality of the product. Boards are set at the sides of the rows and tied by wire cross-ties or "spanners." In some cases terra-cotta tiles are used to blanch the individual plants.

Although celery is usually planted upon land which must be partially or wholly drained, the most profitable celery fields in southern latitudes are irrigated during the growing season. The same tile system used for drainage may also be made to serve for subirrigation. There are certain advantages in cheapness due to this double use of the tile, but the water is applied below the usual feeding zone of the roots and is likely to drain away with low irrigation efficiency. A considerable part of the warming and aerating effect is also lost. Moreover, in mucky or sandy lands there is great danger that after a few years the outpouring of irrigation water from the joints of the tile and the inpouring of drainage water at other seasons of the year may have caused very unequal settling of tile lines, with serious disalignment of the drainage-irrigation system and large loss to the grower.

Surface irrigation by the furrow system is the simplest and cheapest when a low but perceptible grade can be given to the rows, so as to secure a gentle flow of the water without danger of eroding the soft, mucky soils.

Various costly sprinkler systems have been devised and some of them profitably used, but in regions of considerable rainfall the furrow system is usually adequate for the two or three irrigations required while the celery is making its greatest growth, preceding the blanching.

Celery requires fertilization, even upon fertile mucky lands. Stable manure, well rotted, should be worked into the trenches some time before the celery is transplanted, and chemical fertilizers high in potash salts have been found very effective. During the growing season nitrate of soda can profitably be applied to the crop to force growth and thereby give crispness to the stalk. Though the majority of first-class celery soils contain considerable nitrogen in the organic matter of the soil, the nitrate of soda is used to advantage for forcing purposes.

A good crop of celery should bunch out 20,000 or more "single" plants to be washed, sorted, and tied in bundles of a dozen plants each. This would give 1,650 bunches or more, selling at 15 to 25 cents per bunch. Much larger yields and higher prices are obtained by the best growers. A gross return of $\$ 250$ per acre is not high,

[Cir, 19] 
and a gross return of $\$ 500$ per acre has many times been exceeded. The total cost of growing, washing, bunching, and marketing will vary with the scale upon which the operations are conducted, the skill of the producer, and the local conditions of labor cost, price of land, and ease or difficulty of tillage. It should not greatly exceed $\$ 100$ per acre.

Next to celery, and possibly exceeding celery as a profitable crop upon the Portsmouth fine sandy loam, would be the onion crop. The soil requirements of onions are fulfilled by this soil type, and yields of 300 to 600 bushels per acre have been secured on closely similar soils. Unlike celery, onions are seeded directly in the field, and their cultivation is more largely accomplished by hand labor, with hoe and rake. Nevertheless the cost of production is no greater for the onions, and a gross return of $\$ 150$ to $\$ 300$ per acre can be secured. Onions also enter conveniently into a crop rotation which includes celery.

Winter cabbage will produce large yields upon the Portsmouth fine sandy loam, but will require a longer time for growth than upon the early truck soils of the Norfolk series.

Among market garden crops, beets, carrots, turnips, spinach, kale, and collards may be grown on the Portsmouth fine sandy loam. Among forage crops the Ironclad and Whippoorwill varieties of cowpeas are successful, while vetch also produces a large crop. For corn, the Portsmouth fine sandy loam, when properly drained, is excellent.

\section{SUMMARY.}

Savannah, Chatham County, Ga., is situated on the coast, in a region fitted by climate, soils, and transportation facilities for the growing of early vegetables for northern markets.

The Norfolk and Portsmouth series comprise the important truck soils of the Atlantic coast.

The best truck soils of these series are developed extensively within easy hauling distance of Savannah.

Considerable trucking is now done in the neighborhood of Savannah on these soils.

Thousands of acres of the best trucking land are available here for the extension of the trucking industry.

On the Norfolk fine sand, which is, all things considered, the best early truck soil of the eastern United States, early potatoes lead, with snap beans, lettuce, and cucumbers important products. The local adaptation of the soil to these crops is demonstrated by the usual good profits made, and there can be no doubt of the successful development of trucking on areas of this soil. 
Though less extensively developed than the Norfolk fine sand, the Norfolk fine sandy loam is an important truck soil. It is used for the same crops as the fine sand, and compensates for later maturity of the crops by somewhat larger yields. It is especially suited to winter and early spring cabbage, though this crop is not grown about Savannah.

The Portsmouth fine sand needs drainage, is not as early as the Norfolk soils described, and potatoes grown on it are not of as high quality as those produced on the naturally well-drained soils. It will produce early cabbage, late strawberries, and radishes and onions. It can frequently be used most profitably for lettuce, for which it is especially suited. Beets, carrots, collards, and eggplant also thrive upon this soil.

When drained the Portsmouth fine sandy loam is one of the most valuable special truck soils. No soil in the vicinity of Savannah can equal this in the production of celery and onions. Winter cabbage, beets, carrots, turnips, spinach, kale, and collards are other crops suited to soils of this character.

\section{JAY A. Bonsteel, \\ In charge of Soil Survey, Eastern Division.}

Approved :

JAMes Wilson,

Secretary of Agriculture.

Washington, D. C., June 7, 1909.

[Cir. 19] 


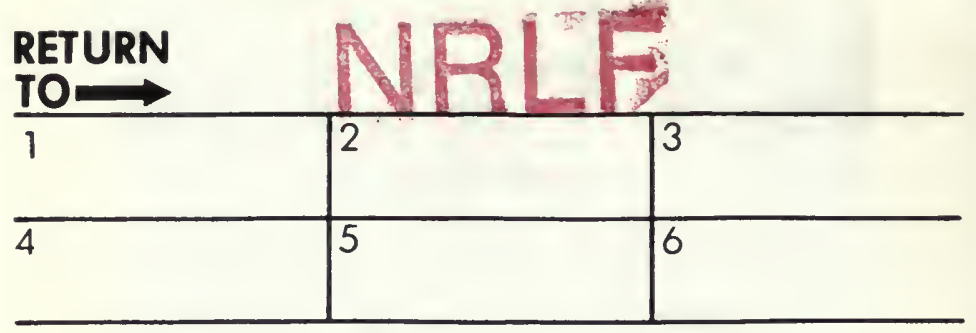

ALL BOOKS MAY BE RECALLED AFTER 7 DAYS

\begin{tabular}{l|l|l}
\hline \multicolumn{2}{c}{ DUE AS STAMPED BELOW } \\
\hline SENT ON ILL & & \\
\hline JAN 101995 & & \\
\hline U.C. BERKELEY & & \\
\hline & & \\
\hline JUL 23 1996 & & \\
\hline F. . E IVED & & \\
\hline JUL 19 1996 & & \\
\hline CIRCULATIONDE: & & \\
\hline & & \\
\hline & & \\
\hline
\end{tabular}


YC 67891

U. C. BERKELEY LIBRARIES I"น

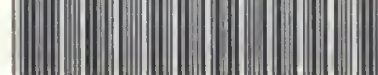
C057093926

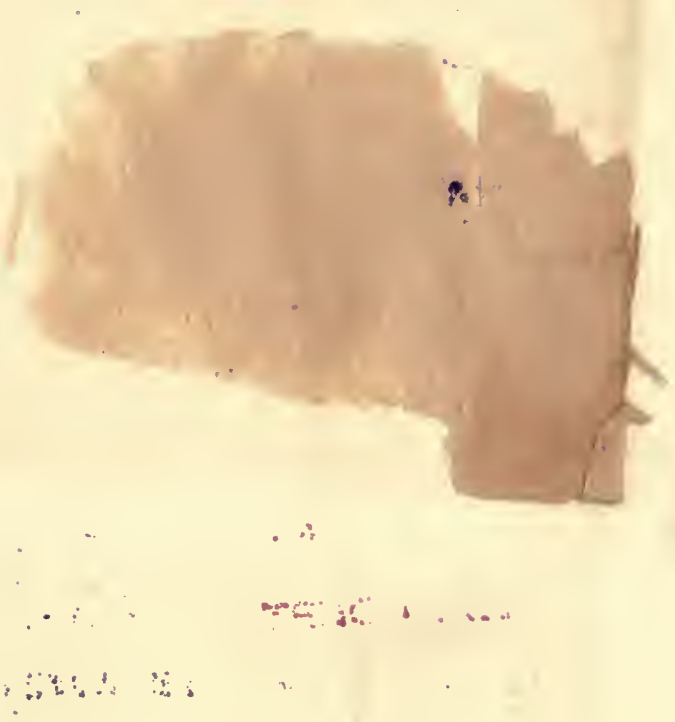




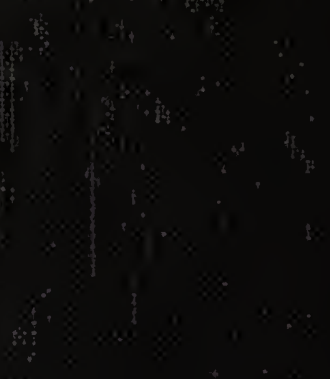

